
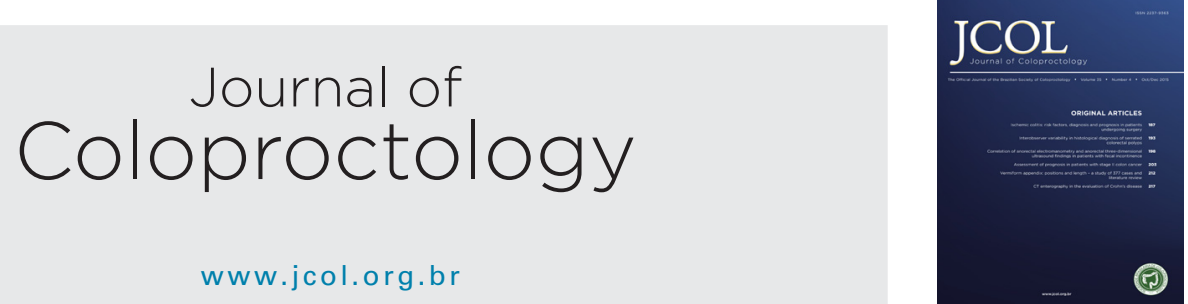

Original Article

\title{
Educational handbook for healthcare professionals: Preventing complications and treating peristomal skin
}

\author{
Geraldo Magela Salomé (i) *, André Luiz da Cunha, Antônio Pedro Pereira, \\ Flávio Dutra Miranda, José Ronaldo Alves
}

Universidade do Vale do Sapucaí (UNIVAS), Pouso Alegre, MG, Brazil

\section{A R T I C L E I N F O}

\section{Article history:}

Received 22 June 2019

Accepted 28 July 2019

Available online 17 September 2019

\section{PALAVRAS-CHAVE:}

Estomia

Dermatite

Cuidados de enfermagem

Manual

\begin{abstract}
A B S T R A C T
Objective: To create and validate a handbook for the prevention of peristomal skin complications.

Methods: For the elaboration of the handbook, a literature review was conducted in the following databases: Cochrane Library, SciELO, LILACS, and MEDLINE. The handbook "Preventing and treating the complications of intestinal peristomal skin" was elaborated in nine steps. The first step addressed the concepts of ostomy, stoma type, and ostomy classification. In the second step, the following were described: definition of the collection equipment, type of collection equipment, and technique of changing one- and two-piece equipment. In the third step, the peristomal skin cleansing technique was described. In the fourth step, the types of complications of the peristomal skin were listed. In the fifth step, preventive approaches to avoid complications with the peristomal skin were described. In the sixth step, the therapeutic approaches in the treatment of aforementioned peristomal skin complications were addressed. In the seventh step, the handbook layout was created by an Information Technology professional. In the eighth step, the handbook was validated by 25 nurses. In the ninth step, the final version of the instrument was laid out.

Results: The final version of the "Preventing and treating the complications of intestinal peristomal skin" handbook has 37 pages. It was registered in the International Standard Book Number: 978-85-67647-46-3, standard format size ( $21 \mathrm{~cm}$ high by $15 \mathrm{~cm}$ wide), totaling 50 illustrations. In the first evaluation, the evaluators assessed the manual as partially adequate to completely adequate. In the first evaluation, the content validity index ranged between 0.88 to 1.0 ; no $100 \%$ agreement was observed among the evaluators' answers. In the second evaluation, as an agreement was observed in all items, the content validity index was 1.0.
\end{abstract}

\footnotetext{
* Corresponding author.

E-mail: salomereiki@yahoo.com.br (G.M. Salomé).

https://doi.org/10.1016/j.jcol.2019.07.005

2237-9363/@ 2019 Sociedade Brasileira de Coloproctologia. Published by Elsevier Editora Ltda. This is an open access article under the CC BY-NC-ND license (http://creativecommons.org/licenses/by-nc-nd/4.0/).
} 
Conclusion: The handbook "Preventing and treating the complications of intestinal peristomal skin" was elaborated based on scientific principles and had its content, language, and design validated by specialists in the field.

○ 2019 Sociedade Brasileira de Coloproctologia. Published by Elsevier Editora Ltda. This is an open access article under the CC BY-NC-ND license (http://creativecommons.org/ licenses/by-nc-nd/4.0/).

\title{
Manual educativo para profissional da área da saúde: prevenindo complicação e tratando a pele periestoma
}

\author{
R E S U M O
}

Keywords:

Ostomy

Dermatitis

Nursing care

Handbook
Objetivo: Construir e validar um manual para a prevenção das complicações da pele periestoma.

Método: Para a construção do manual, realizou-se uma revisão nas bases: Biblioteca Cochrane, SciELO, LILACS e MEDLINE. O manual "Prevenindo e tratando das complicações da pele periestoma intestinal" foi elaborado em nove etapas. A primeira etapa abordou os conceitos de estomia, tipo de estoma, classificação de estomia. Na segunda etapa, foram elaborados: definição de equipamento coletor, tipo de equipamentos coletores, técnica da troca do equipamento de uma e duas peças. Na terceira etapa, definiu-se a técnica de limpeza da pele periestoma. Na quarta etapa, foram descritos os tipos de complicações da pele periestoma. Na quinta etapa, enfocaram-se as condutas preventivas para evitar as complicações com a pele periestoma. Na sexta etapa, foram descritas as condutas terapêuticas no tratamento das complicações da pele periestoma citadas acima. Na sétima etapa, foi realizada a diagramação do manual por um profissional da área de Tecnologia da Informação. Na oitava etapa, validação do manual por 25 enfermeiros. A nona etapa correspondeu à diagramação da versão final do instrumento.

Resultados: A versão final do manual denominado "Prevenindo e tratando das complicações da pele periestoma intestinal" contém 37 páginas. Foi registrado no International Standard Book Number: 978-85-67647-46-3, tamanho padrão de formatação com $21 \mathrm{~cm}$ de altura por $15 \mathrm{~cm}$ de largura, totalizando 50 ilustrações. Na primeira avaliação, os juízes avaliaram o manual como parcialmente adequado a totalmente adequado. $O$ Índice de validade de conteúdo na primeira avaliação foi entre 0,88 a 1,0; não tendo ocorrido $100 \%$ de concordância das respostas dos juízes; na segunda avaliação, tendo havido concordância dos juízes em todos os itens, o índice de validade de conteúdo foi 1,0.

Conclusão: O manual intitulado "Prevenindo e tratando das complicações da pele periestoma intestinal" foi construído com embasamento científico, validado quanto ao conteúdo, à linguagem e à aparência por especialistas na área.

(C) 2019 Sociedade Brasileira de Coloproctologia. Publicado por Elsevier Editora Ltda. Este é um artigo Open Access sob uma licença CC BY-NC-ND (http://creativecommons.org/ licenses/by-nc-nd/4.0/).

\section{Introduction}

Individuals with intestinal stoma should receive humanized care and have their clinical status assessed through physical examination and anamnesis, valuing the patient's verbal and nonverbal reports. Thus, it is necessary to systematize the care to ostomized patients. This assistance promotes patients' rehabilitation and minimizes their suffering, especially by encouraging self-care, and preventing beliefs and taboos from becoming threats to their physical, social, and psychological integrity. Another goal is to eliminate the fear of self-care. ${ }^{1-7}$

In peristomal skin care, demarcation should be done before surgery, as proper location will facilitate self-care and contribute to the social reintegration of the stoma patient. The first exchange of the bag is another important moment for both the patient and the family member who will care for them, and should be considered by the nurse as the initial demonstration of the practice of activities and skills inherent to the self-care in stoma and peristomal skin. ${ }^{8-12}$ If performed correctly, these procedures prevent complications.

The elaboration of protocols, handbooks, booklets, algorithms, guides, and guidelines based on the best-known evidence support the provision of care based on good clinical practices and allow patient recovery. In this sense, the applicability of guidelines for care is increasingly necessary for consolidating some aspects of the clinical practice of healthcare professionals, as it systematizes care and objectively establishes steps and conducts to address a particular issue. Therefore, the practitioner should be concerned with collecting valid information in the scientific literature to assist in the 
diagnosis, prognosis, prevention, effective therapy, intervention, or other clinical issues of interest. ${ }^{12,13}$

Thus, the creation and validation of a handbook to prevent complications in peristomal skin was warranted, aiming to help healthcare professionals prevent and treat complications in ostomized individuals, which can bring severe physical and psychological consequences to affected patients and substantial financial costs to healthcare systems worldwide. The elaboration of this material is extremely relevant to address these complications, given the significant increase in the incidence of individuals with intestinal ostomy in recent decades.

\section{Objective}

To create and validate a handbook for the prevention of peristomal skin complications.

\section{Methods}

This was a methodological study. The handbook elaboration process took place between February and December, 2017, and expert validation occurred between March and October, 2018. The study was approved by the Research Ethics Committee of the Faculdade de Ciências da Saúde "Dr. José Antônio Garcia Coutinho" under opinion No. 1.108.429.

For the elaboration of the handbook "Preventing and treating the complications of intestinal peristomal skin", a review was made in Health Sciences databases, including the Cochrane Library, SciELO, LILACS, and MEDLINE. Ostomy was the descriptor used.

To select the content of the publications to be used in the handbook elaboration process, the inclusion criteria were only primary studies that were directly linked to the theme and were available in full and without temporal delimitation, as the intention was to compile all studies that met the established criteria.

The handbook was elaborated in nine steps.

The first step addressed the concepts of ostomy, stoma type, and ostomy classification.

In the second step, the following were described: definition of the collection equipment, type of collection equipment, and technique of changing one- and two-piece equipment.

In the third step, the peristomal skin cleansing technique was described.

The fourth step described the types of peristomal skin complications (irritative dermatitis, allergic dermatitis, mechanical trauma dermatitis, retraction, prolapse, mucocutaneous detachment).

In the fifth step, preventive approaches to avoid complications with the peristomal skin were described.

In the sixth step, the therapeutic approaches in the treatment of aforementioned peristomal skin complications were addressed.

In the seventh step, the handbook layout was created by an Information Technology professional.

In the eight step, the first version of the manual (properly laid out) was sent to health professionals (evaluators) to evaluate the material.
In the ninth step, the final version of the instrument was laid out.

After its construction, the manual was validated by 25 evaluators (nurses).

To participate in the study, the evaluators had to be professional nurses, with undergraduate degree in Nursing, and to have a minimum experience of 1 year in the treatment of individuals with intestinal stoma. Those who accepted to participate in the research, but did not respond or did not send back the completed evaluation questionnaire within ten days, were excluded.

An invitation letter was sent to the evaluators by e-mail or delivered in person. The letter consisted of an initial personal presentation and clarifications on the research theme, the Opinion of the Institutional Research Ethics Committee, and step-by-step explanations of the stages to allow an effective participation of the evaluators. The ten-day deadline for returning the completed questionnaire was set from the day of the invitation to participate in the study.

The handbook evaluation questionnaire was divided into two parts. The first part consisted of evaluator identification (time since graduation, time of experience, postgraduate course).

The second part of the questionnaire was designed to validate the handbook, with 22 multiple-choice questions related to: graphical presentation, readability, vocabulary, handbook sequence, technical updatedness, ostomy concepts, ostomy classification, type of collecting equipment, technique for exchanging one- and two-piece equipment, peristomal skin cleansing technique, types of peristomal skin complications, preventive approaches to prevent peristomal skin complications, and therapeutic approaches in the treatment of the aforementioned peristomal skin complications.

To validate the content of the manual, the Delphi technique was used; for statistical analysis, Cronbach's alpha and content validity index tests were used.

The Delphi technique uses questionnaires to evaluate the content of an instrument by experts in search of a 50\%-100\% consensus among them. Usually two or three rounds of assessment are conducted; more may be performed. After the review, items classified as "inadequate," "partially adequate," and "not applicable" in the first round are resubmitted to the evaluators for the second round of evaluation, seeking a consensus of approval among the evaluators. In the present study, a $100 \%$ consensus among the evaluators was adopted.

Data were analyzed and correlated to determine Cronbach's alpha coefficient, which aims to estimate the internal reliability of the instrument. The higher the covariances or correlations between the items (i.e., the closer the value obtained is equal to one), the greater the homogeneity of the items and the consistency with which they measure the same theoretical dimension or construct. Cronbach's alpha test $\alpha>0.700$.

The content validity index measures the proportion or percentage of evaluators who agree with certain aspects of the instrument and its items. Only responses marked "adequate" or "completely adequate" were considered for the content validity index calculation. A minimum agreement of $90 \%$ $(\mathrm{CVI} \geq 0.90)$ among evaluators is required for the validation of the handbook. 


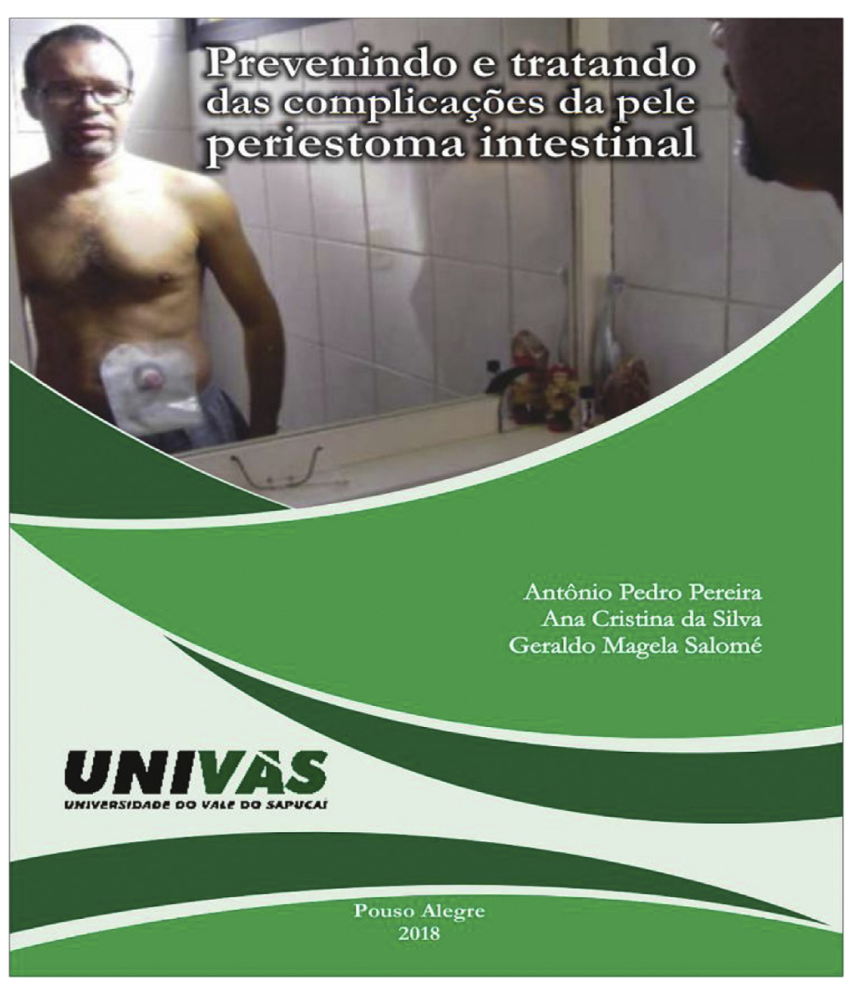

Fig. 1 - Cover of the handbook "Preventing and treating the complications of intestinal peristomal skin”. Pouso Alegre, MG, Brazil, 2018.

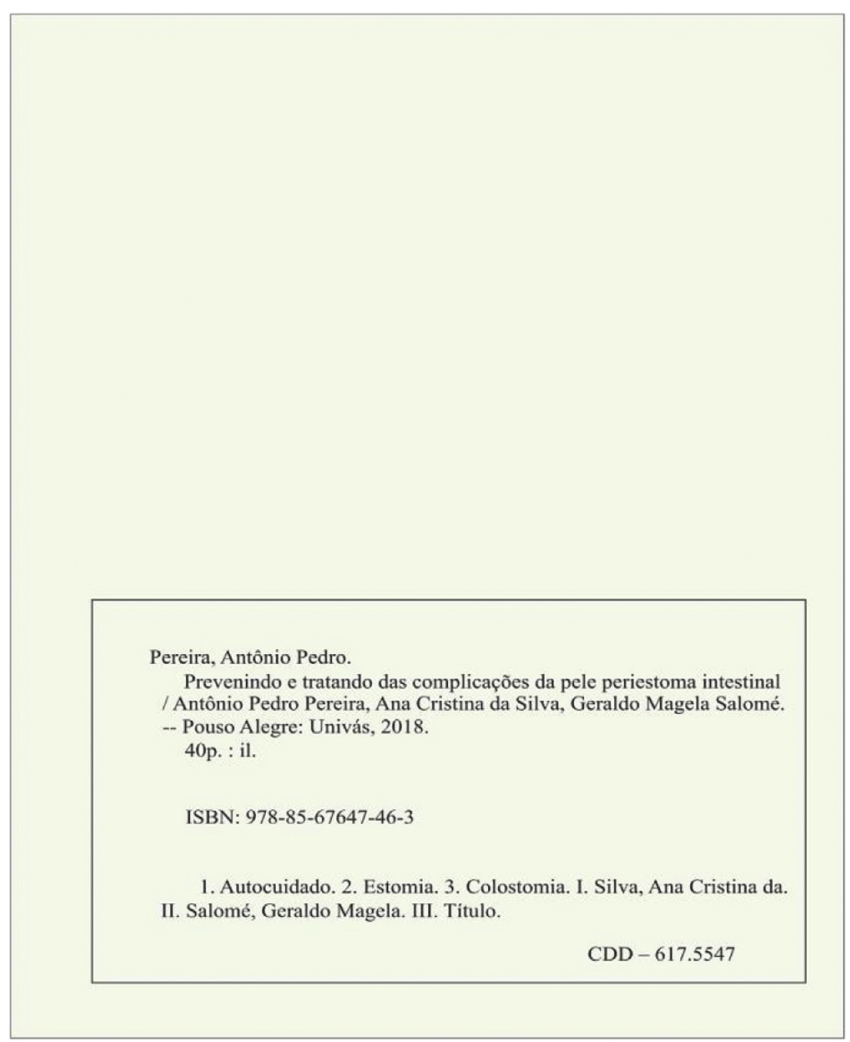

Fig. 2 - Catalogue page of the handbook "Preventing and treating the complications of intestinal peristomal skin". Pouso Alegre, MG, Brazil, 2018.

\section{SUMÁRIO}

\begin{tabular}{|c|c|}
\hline \multicolumn{2}{|r|}{ Apresentação } \\
\hline 1. & Definição de estoma \\
\hline 2. & 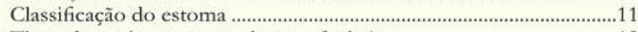 \\
\hline 3. & Tipos de equipamentos coletores (bolsa) ........ \\
\hline 4. & 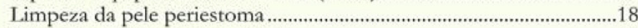 \\
\hline 5. & 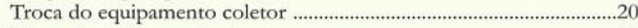 \\
\hline 5.1 & Troca do equipamento de uma peça ..................... \\
\hline 5.2 & Troca do equipamento de duas peças . \\
\hline 6. & Tipos de complicações ............................. \\
\hline 6.1 & 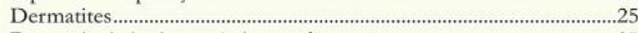 \\
\hline 6.1 .1 & Dermatite irritativa, química ou de contato......... \\
\hline 6.1 .2 & Cuidados c \\
\hline 6.1 .3 & 'Técnicas do autocuidado ........... \\
\hline 6.1.4 & Técnica para fixação da bolsa .. \\
\hline 6.1 .5 & 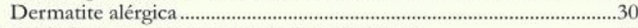 \\
\hline 6.1.5.1 & 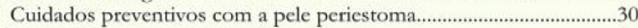 \\
\hline 6.1 .6 & 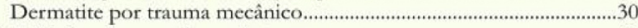 \\
\hline 6.1.6.1 & 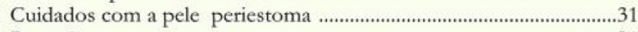 \\
\hline 6.2 & 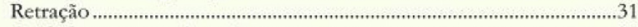 \\
\hline 6.2 .1 & Cuidados com a pele periestoma \\
\hline 6.3 & Prolapso \\
\hline 6.3 .1 & Cuidados com a pele periestoma ...... \\
\hline 6.4 & 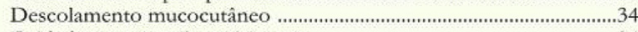 \\
\hline 6.4.1 & Cuidados com a pele periestoma \\
\hline 7. & Apresentação de imagens relativas a estudo de caso \\
\hline 7.1 & 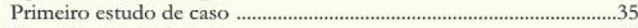 \\
\hline 7.2 & 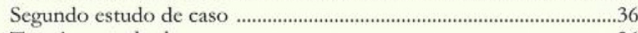 \\
\hline 7.3 & Terceiro estudo de caso \\
\hline
\end{tabular}

Fig. 3 - Summary of the handbook "Preventing and treating the complications of intestinal peristomal skin". Pouso Alegre, MG, Brazil, 2018.

\section{Results}

The final version of the "Preventing and Treating Complications of Intestinal Peristomal Skin" handbook has 37 pages, including the cover, back cover with the cataloging sheet and the International Standard Book Number: 978-85-67647-463 , illustration list, chart list, summary, preface, presentation, seven chapters, concluding remarks, and bibliographic references, in standard format size $(21 \mathrm{~cm}$ high by $15 \mathrm{~cm}$ wide). Each page has up to 10 illustrations, totaling 50 illustrations (Figs. 1-3). The handbook is available, free of charge, at: http://www.univas.edu.br/menu/biblioteca/publicacoes.asp.

Table 1 presents the evaluators' assessment of the characteristics of the handbook. In the first evaluation, the handbook was assessed as partially adequate to completely adequate. After the corrections of the evaluators, the handbook was resubmitted to the evaluators, being reassessed as appropriate and completely adequate.

Table 2 shows that the questionnaire presented to the evaluators for the validation of the handbook contributed to the internal consistency of the instrument (0.9748). Such findings indicate that the questionnaire used by the evaluators to assess the handbook presented excellent internal consistency.

Table 3 presents the content validity index, demonstrating that all questions in the first evaluation were scored between 0.88 to 1.0 , and there was no agreement by the evaluators in 
Table 1 - Evaluation of questions in the handbook "Preventing and treating the complications of intestinal peristomal skin" by the research participants, using the Delphi technique. Pouso Alegre, MG, Brazil, 2018.

Questions

First assessment (Delphi technique)

\begin{tabular}{|c|c|c|c|c|c|c|c|c|c|c|}
\hline & \multirow{2}{*}{\multicolumn{2}{|c|}{ Inadequate }} & \multirow{2}{*}{\multicolumn{2}{|c|}{ Partially adequate }} & \multirow{2}{*}{\multicolumn{2}{|c|}{ Adequate }} & & & \multirow{2}{*}{\multicolumn{2}{|c|}{ Total }} \\
\hline & & & & & & & \multicolumn{2}{|c|}{ Completely adequate } & & \\
\hline & $\mathrm{n}$ & $\%$ & $\mathrm{n}$ & $\%$ & $\mathrm{n}$ & $\%$ & $\mathrm{n}$ & $\%$ & $\mathrm{n}$ & $\%$ \\
\hline Vocabulary & 0 & 0 & 1 & 4 & 9 & 36 & 15 & 60 & 25 & 100 \\
\hline Technical updatedness & 0 & 0 & 0 & 0 & 4 & 16 & 21 & 84 & 25 & 100 \\
\hline Spelling & 0 & 0 & 0 & 0 & 8 & 32 & 17 & 68 & 25 & 100 \\
\hline Readability & 0 & 0 & 1 & 4 & 10 & 40 & 14 & 56 & 25 & 100 \\
\hline Handbook sequence & 0 & 0 & 1 & 4 & 9 & 36 & 15 & 60 & 25 & 100 \\
\hline Stoma concept & 0 & 0 & 0 & 0 & 8 & 32 & 17 & 68 & 25 & 100 \\
\hline Stoma classification & 0 & 0 & 1 & 4 & 10 & 40 & 14 & 56 & 25 & 100 \\
\hline Collection equipment & 0 & 0 & 3 & 12 & 6 & 24 & 16 & 64 & 25 & 100 \\
\hline Peristomal skin cleansing & 0 & 0 & 1 & 4 & 10 & 40 & 14 & 56 & 25 & 100 \\
\hline Collector equipment exchange & 1 & 4 & 0 & 0 & 8 & 32 & 16 & 64 & 25 & 100 \\
\hline One piece collector & 0 & 0 & 1 & 4 & 7 & 28 & 17 & 68 & 25 & 100 \\
\hline Two piece collector & 0 & 0 & 2 & 8 & 7 & 28 & 16 & 64 & 25 & 100 \\
\hline Types of complications & 0 & 0 & 0 & 0 & 7 & 28 & 18 & 72 & 25 & 100 \\
\hline Definition of dermatitis & 0 & 0 & 1 & 4 & 9 & 36 & 15 & 60 & 25 & 100 \\
\hline Chemical dermatitis & 0 & 0 & 1 & 4 & 9 & 36 & 15 & 60 & 25 & 100 \\
\hline Allergic dermatitis & 0 & 0 & 1 & 4 & 9 & 36 & 15 & 60 & 25 & 100 \\
\hline Mechanical dermatitis & 0 & 0 & 0 & 0 & 9 & 36 & 16 & 64 & 25 & 100 \\
\hline Retraction description & 0 & 0 & 1 & 4 & 8 & 32 & 16 & 64 & 25 & 100 \\
\hline Prolapse description & 0 & 0 & 3 & 12 & 10 & 40 & 12 & 48 & 25 & 100 \\
\hline Detachment description & 0 & 0 & 1 & 4 & 9 & 36 & 15 & 60 & 25 & 100 \\
\hline $\begin{array}{l}\text { Preventive care to avoid } \\
\text { complications }\end{array}$ & 0 & 0 & 1 & 4 & 8 & 32 & 16 & 64 & 25 & 100 \\
\hline $\begin{array}{l}\text { Therapeutic approaches for the } \\
\text { treatment of complications. }\end{array}$ & 0 & 0 & 0 & 0 & 8 & 32 & 17 & 68 & 25 & 100 \\
\hline \multirow[t]{2}{*}{ Case study } & 0 & 0 & 0 & 0 & 10 & 40 & 15 & 60 & 25 & 100 \\
\hline & \multicolumn{4}{|c|}{ Second assessment (Delphi technique) } & & & & & & \\
\hline Vocabulary & 0 & 0 & 0 & 0 & 10 & 40 & 15 & 60 & 25 & 100 \\
\hline Technical updatedness & 0 & 0 & 0 & 0 & 4 & 16 & 21 & 84 & 25 & 100 \\
\hline Spelling & 0 & 0 & 0 & 0 & 8 & 32 & 17 & 68 & 25 & 100 \\
\hline Readability & 0 & 0 & 0 & 0 & 11 & 40 & 14 & 56 & 25 & 100 \\
\hline Handbook sequence & 0 & 0 & 0 & 0 & 9 & 36 & 16 & 64 & 25 & 100 \\
\hline Stoma concept & 0 & 0 & 0 & 0 & 8 & 32 & 17 & 68 & 25 & 100 \\
\hline Stoma classification & 0 & 0 & 0 & 0 & 10 & 40 & 15 & 60 & 25 & 100 \\
\hline Collection equipment & 0 & 0 & 0 & 0 & 8 & 32 & 17 & 68 & 25 & 100 \\
\hline Peristomal skin cleansing & 0 & 0 & 0 & 0 & 11 & 44 & 14 & 56 & 25 & 100 \\
\hline Collector equipment exchange & 0 & 0 & 0 & 0 & 9 & 36 & 16 & 64 & 25 & 100 \\
\hline One piece collector & 0 & 0 & 0 & 0 & 7 & 28 & 18 & 72 & 25 & 100 \\
\hline Two piece collector & 0 & 0 & 0 & 0 & 9 & 36 & 16 & 64 & 25 & 100 \\
\hline Types of complications & 0 & 0 & 0 & 0 & 7 & 28 & 18 & 72 & 25 & 100 \\
\hline Definition of dermatitis & 0 & 0 & 0 & 0 & 9 & 36 & 16 & 64 & 25 & 100 \\
\hline Chemical dermatitis & 0 & 0 & 0 & 0 & 10 & 40 & 15 & 60 & 25 & 100 \\
\hline Allergic dermatitis & 0 & 0 & 0 & 0 & 9 & 36 & 16 & 64 & 25 & 100 \\
\hline Mechanical dermatitis & 0 & 0 & 0 & 0 & 9 & 36 & 16 & 64 & 25 & 100 \\
\hline Retraction description & 0 & 0 & 0 & 0 & 8 & 32 & 17 & 68 & 25 & 100 \\
\hline Prolapse description & 0 & 0 & 0 & 0 & 11 & 44 & 14 & 56 & 25 & 100 \\
\hline Detachment description & 0 & 0 & 0 & 0 & 10 & 40 & 15 & 60 & 25 & 100 \\
\hline $\begin{array}{l}\text { Preventive care to avoid } \\
\text { complications }\end{array}$ & 0 & 0 & 0 & 0 & 8 & 32 & 17 & 68 & 25 & 100 \\
\hline $\begin{array}{l}\text { Therapeutic approaches for the } \\
\text { treatment of complications }\end{array}$ & 0 & 0 & 0 & 0 & 8 & 32 & 17 & 68 & 25 & 100 \\
\hline Case study & 0 & 0 & 0 & 0 & 10 & 40 & 15 & 60 & 25 & 100 \\
\hline
\end{tabular}

this first evaluation. After adjustments made based on the suggestions of the evaluators, the handbook was reevaluated, and the evaluators agreed on all items, with a content validity index of 1.0.

\section{Discussion}

The use of an educational instrument (handbooks, booklets, applications, online course) that was created with an active 
Table 2 - Evaluation of questions in the handbook

"Preventing and treating the complications of intestinal peristomal skin" by the research participants, using Cronbach's alpha. Pouso Alegre, MG, Brazil, 2018.

\begin{tabular}{ll} 
Questions & Cronbach's alpha ${ }^{\mathrm{a}}$ \\
\hline Vocabulary & 0.9736 \\
Technical updatedness & 0.9748 \\
Spelling & 0.9748 \\
Readability & 0.9729 \\
Handbook sequence & 0.9730 \\
Stoma concept & 0.9727 \\
Stoma classification & 0.9730 \\
Collection equipment & 0.9746 \\
Peristomal skin cleansing & 0.9750 \\
Collector equipment exchange & 0.9764 \\
One piece collector & 0.9722 \\
Two piece collector & 0.9738 \\
Types of complications & 0.9740 \\
Definition of dermatitis & 0.9728 \\
Chemical dermatitis & 0.9728 \\
Allergic dermatitis & 0.9743 \\
Mechanical dermatitis & 0.9729 \\
Retraction description & 0.9723 \\
Prolapse description & 0.9757 \\
Detachment description & 0.9730 \\
Preventive care to avoid complications & 0.9723 \\
Therapeutic approaches for the treatment & 0.9727 \\
$\quad$ of complications. & \\
Case study & 0.9740 \\
Cronbach's $\alpha$ coefficient & 0.9748 \\
\hline
\end{tabular}

Cronbach's $\alpha$ test.

a Significance level $\alpha>0.700$.

participation of professionals with experience in the area is paramount for the provision of individualized, systematized care, promoting patient safety and resulting in an improvement in the quality of care. ${ }^{13-16}$

Educational materials are facilitating devices of the teaching-learning process, allowing the transfer of knowledge through the involvement and participation of the individual and creating a possibility for exchanging experiences, leading to skills improvement. These materials have been widely used for health education, being vehicles of knowledge dissemination, aiming to contribute to the improvement of living conditions and health of the population. ${ }^{17,18}$

Table 3 - Content validity index regarding the adequacy of the items in the handbook "Preventing and treating the complications of intestinal peristomal skin" by the research participants. Pouso Alegre, MG, Brazil, 2018.

Questions

Content Validity Index ${ }^{a}$

\begin{tabular}{lll} 
& $1^{\text {st }}$ evaluation & $2^{\text {nd }}$ evaluation \\
\hline Vocabulary & 0.96 & 1.0 \\
Technical updatedness & 1.00 & 1.0 \\
Spelling & 1.00 & 1.0 \\
Readability & 0.96 & 1.0 \\
Handbook sequence & 0.96 & 1.0 \\
Stoma concept & 1.00 & 1.0
\end{tabular}

Table 3 (Continued)

Questions

Content Validity Index

\begin{tabular}{lll} 
& $1^{\text {st }}$ evaluation & $2^{\text {nd }}$ evaluation \\
\hline Stoma classification & 0.96 & 1.0 \\
Collection equipment & 0.88 & 1.0 \\
Peristomal skin cleansing & 0.96 & 1.0 \\
Collector equipment exchange & 0.96 & 1.0 \\
One piece collector & 0.96 & 1.0 \\
Two piece collector & 0.92 & 1.0 \\
Types of complications & 1.00 & 1.0 \\
Definition of dermatitis & 0.96 & 1.0 \\
Chemical dermatitis & 0.96 & 1.0 \\
Allergic dermatitis & 0.96 & 1.0 \\
Mechanical dermatitis & 1.00 & 1.0 \\
Retraction description & 0.96 & 1.0 \\
Prolapse description & 0.88 & 1.0 \\
Detachment description & 0.96 & 1.0 \\
Preventive care to avoid & 0.96 & 1.0 \\
$\quad$ complications & & \\
Therapeutic approaches for the & 1.00 & 1.0 \\
$\quad$ treatment of complications. & & \\
Case study & 1.00 & 1.0 \\
Global content validity index & 0.96 & 1.0 \\
\hline
\end{tabular}

Content validity index.

a CVI significance $>0.90$.

In this study, the evaluators' answers regarding the internal reliability of the questionnaire used to assess the handbook allowed the calculation of the Cronbach's alpha index (0.9748), which indicates that the instrument has excellent internal reliability.

Corroborating these data, and comparing them with the findings of other methodological studies of the development of handbooks, booklets, protocols, applications, which report the importance of evaluating the internal consistency of the instrument to be used, Cronbach's alpha is used to estimate the internal reliability of an instrument applied in a research. It measures the correlation among the answers in a questionnaire by analyzing the answers given by the respondents, presenting an average correlation between the questions. ${ }^{12,13,19-22}$

The assessment of a handbook (a fundamental step to identify the weaknesses and limitations of the product) must be done by professionals with experience in the area, who will analyze its content, coherence, vocabulary, and relevance of information provided. If the evaluators suggest alterations in any topic, the researcher should always make corrections based on the available evidence. ${ }^{19,23}$

The contents of the handbook were validated using the Delphi technique. The handbook was only validated in the second evaluation, when a consensus among the evaluators' answers was achieved. It is necessary to emphasize that the evaluators, when assessing the material, registered their contributions and observations, in order to ensure that the population would access an educational material of highest quality. The necessary adjustments to the manual were made and resubmitted to the evaluators. Only in this second evaluation was the validation of the manual completed. Several researchers consider that such details contribute to the enrichment of the final product and to the improvement of its applicability, through 
the reformulation of information, substitution of terms, and revision of the illustrations. ${ }^{19,23}$

Currently, measurement instruments have been used to aid content validation, being tools that measure indicators and assign numerical values to abstract concepts, which can be observable and measurable, contributing to improve healthcare praxis. ${ }^{24}$

\section{Conclusion}

It is possible to conclude that the proposed objective of the study was achieved, since the handbook "Preventing and treating the complications of intestinal peristomal skin" was elaborated based on scientific principles and had its content, language, and design validated by specialists in the field.

\section{Conflicts of interest}

The authors declare no conflicts of interest.

\section{Acknowledgements}

There was no external funding for this study. The authors would like to acknowledge the scholarship from the Undergraduate Scholarship Program (PROBIC) of the Foundation for Research Support of the State of Minas Gerais (FAPEMIG).

\section{REFERE NCES}

1. Costa VF, Alves SG, Eufrásio C, Salomé GM, Ferreira LM. Body image and subjective well-being in ostomists in Brazil. Gastrointestinal Nursing. 2014;12:37-40.

2. Salles VEJA, Becker CPP, Faria GMR. The influence of time on the quality of life of patients with intestinal stoma. J Coloproctol. 2014;34:73-5.

3. Salome GM, Almeida SA. Association of sociodemographic and clinical factors with the self-image and self-esteem of individuals with intestinal stoma. J Coloproctol. 2014;34:159-66.

4. Salomé GM, Almeida SA, Mendes B, Carvalho MRF, Junior MRM. Assessment of subjective well-being and quality of life in patients with intestinal stoma. J Coloproctol. 2015;35:168-74.

5. Aguiar ESS, Santos AAR, Soares MJGO, Ancelmo MN, Silva, Santos SR. Complicaciones del estoma y de la piel periestomal com pacientes com estomas intestinales. Estima. 2011;9:22-30.

6. Salomé GM, Santos LF, Cabeceira HS, Panza AMM, Paula MAB. Knowledge of undergraduate nursing course teachers on the prevention and care of peristomal skin. J Coloproctol. 2014;34:224-30.

7. Moraes JT, Victor DR, Abdo JR, Santos MC, Perdigão MM. Characterization of enerostomal people assisted by the Municipal General Office of Health of Divinópolis-MG. Estima. 2009;7:31-7.
8. Mauricio VC, Oliveira NVD, Lisboa MTL. The nurse and her participation in the process of rehabilitation of the person with a stoma. Esc Anna Nery. 2013;17(3):416-22.

9. Coelho AMS, de Oliveira CG, Bezerra STF, Almeida ANS, Cabral RL, Coelho MMF. Self care of patients with colostomy, peristomal skin and collecting bag. J Nurs UFPE on line. 2015;9, 9528-34.10-10.

10. Cesaretti IUR. Caring for a person with an ostomyin the late postoperative period. Estima. 2008;6:27-32.

11. Neil N, Inglese G, Manson A, Townshend A. A cost-utility model of care for peristomal skin complications. J Wound Ostomy Continence Nurs. 2016;43:62-8.

12. Colwell JC, Kupsick PT, McNichol LL. Outcome criteria for discharging the patient with a new ostomy from home health care: a WOCN Society Consensus Conference. J Wound Ostomy Continence Nurs. 2016;43:269-73.

13. Mendes B, Salomé GM, Pinheiro FAM, Júnior MRM, da Cunha DR, Ferreira LM. Prevention and treatment of the trench foot: validation of a teaching manual for military personnel. J Wound Care. 2018;27(Sup10):S33-8.

14. de Carvalho MRF, Salomé GM, Ferreira LM. Construction and validation of algorithm for treatment of pressure injury. J Nurs UFPE on line. 2017;11 Suppl.10:4171-83.

15. Santos AC, Dutra RAA, Salomé GM, Ferreira LM. Construction and internal reliability of an algorithm for choice cleaning and topical therapy on wounds. J Nurs UFPE online. 2018;12: 680-5.

16. Moura IH, Silva AFR, AESH Rocha, Lima LHO, Moreira TMM, Silva ARV. Construction and validation of educational materials for the prevention of metabolic syndrome in adolescents. Rev Latino-Am Enfermagem. 2017;25: e2934.

17. Salci MA, Maceno P, Rozza SG, Silva DMGV, Boehs AE, Heidemann ITSB. Health education and its theoretical perspectives: a few reflections. Texto Contexto Enferm. 2013;22:224-30.

18. Siddharthan T, Rabin T, Canavan ME, Nassali F, Kirchhoff P, Kalyesubula R, et al. Implementation of patient-centered education for chronic-disease management in Uganda: an effectiveness study. PLoS One. 2016;11:e0166411.

19. Hora HRM, Gina TRMJA. Confiabilidade em questionários para qualidade: um estudo com o coeficiente Alfa de Cronbach. Produto Produção. 2010;11:85-103.

20. Leite SS, Áfio ACE, Carvalho LV, Silva JM, Almeida PC, Pagliuca LMF. Construction and validation of an Educational Content Validation Instrument in Health. Rev Bras Enferm [Internet]. 2018;71 Suppl 4:1635-41.

21. Cunha JB, Dutra RAA, Salomé GM. Elaboration of an algorithm for wound evaluation and treatment. ESTIMA. Braz J Enterostomal Ther. 2018;16:e2018.

22. Tibúrcio MP, Melo GSM, Balduíno LSC, Freitas CCS, Costa IKF, Torres GV. Content validation of an instrument to assess the knowledge about the measurement of blood pressure. Rev Pesqui Cuid Fundam [Internet]. 2015;7:2475-85.

23. Leite SS, Áfio ACE, Carvalho LV, Silva JM, Almeida PC, Pagliuca LMF. Construction and validation of an Educational Content Validation Instrument in Health. Rev Bras Enferm [Internet]. 2018;71 Suppl 4:1635-41.

24. Coluci MZO, Alexandre NMC, Milani D. Construção de instrumentos de medida na área da saúde. Ciênc Saúde Colet [Internet]. 2015;20:925-36. 